\title{
Implementasi Scientific Approach dalam Mengembangkan Multiple Intelligences Anak Usia Dini
}

\author{
Khusnul Laely ${ }^{\circledR}$, Subiyanto ${ }^{2}$ \\ Pendidkan Guru Pendidikan Anak Usia Dini, Universitas Muhammadiyah Magelang(1) \\ Bimbingan Konseling, Universitas Muhammadiyah Magelang(2) \\ DOI: $\underline{10.31004 / o b s e s i . v 5 i 2.730}$
}

\begin{abstract}
Abstrak
Tujuan dalam penelitian ini untuk mengetahui implementasi scientific approach dalam kegiatan bermain anak serta bagaimana scientific approach mampu mengembangkan multiple intelligences anak usia dini. Metode penelitian yang digunakan dalam penelitian ini yaitu metode survey. Penelitian ini menggunakan angket dan lembar observasi sebagai alat penelitian yang dilakukan pada 9 lembaga Pendidikan Anak usia Dini (PAUD) yang berada di Kabupaten Temanggung, Wonosobo, dan Kebumen. Pengumpulan data dengan menggunakan wawancara, angket, dan pengamatan. Analisis data menggunakan deskriptif kuantitatif. Hasil penelitian menunjukkan implementasikan kegiatan pembelajaran dengan menggunakan Scientific Approach baru mencapai 44,44 \%. Hal ini didasarkan pada hasil penelitian dilapangan, guru di lembaga PAUD se Karisidenan Kedu belum semua mampu memberikan kesempatan kepada anak untuk memberikan kesempatan anak mulai dari mengamati, menanya, mengumpulkan informasi, menalar sampai pada mengkomunikasikan. Meskipun demikian, pembelajaran dengan menggunakan Scientific Approach dapat menstimulasi multiple intelligences anak usia dini.
\end{abstract}

Kata Kunci: scientific approach; multiple intelligences; anak usia dini.

\begin{abstract}
The purpose of this study was to determine the extent to which the implementation of the scientific approach in children's play activities and how the scientific approach was able to develop multiple intelligences of early childhood. The research method used in this study is the survey method. This study uses a questionnaire and observation sheet as a research tool conducted at 9 PAUD institutions in Temanggung, Wonosobo, and Kebumen districts. Data collection using interviews, questionnaires, and observations. Data analysis using quantitative descriptive. The results showed that the implementation of learning activities using the Scientific Approach only reached $44.44 \%$. This is based on the results of research in the field, teachers in PAUD institutions throughout the Kedu Residence have not all been able to provide opportunities for children to provide opportunities for children ranging from observing, asking questions, gathering information, reasoning to communicating. Nevertheless, learning by using the Scientific Approach can stimulate multiple intelligences of early childhood.
\end{abstract}

Keywords: scientific approach; multiple intelligences; early childhood.

Copyright (c) 2021 Rachma Hasibuan, Nur Ika Sari Rakhmawati

$\triangle$ Corresponding author :

Email Address: khusnullaely86@ummgl.ac.id (Magelang, Jawa Tengah, Indonesia)

Received 22 August 2020, Accepted 10 January 2021, Published 25 Fabruary 2021 


\section{PENDAHULUAN}

Pada hakikatnya anak usia dini adalah sosok individu yang berada dalam masa keemasan (golden age) yaitu mengalami perkembangan yang fundamental dan pesat dalam perkembangannya. Montessori berpendapat pada masa ini disebut juga periode sensitif (sensitive periods) yaitu anak dengan sangat mudah menerima dan merekam seluruh stimulusstimulus yang didapatkan dari lingkungan (Hainstock, 1999). Periode ini hanya terjadi satu kali selama masa kehidupan anak dan tidak akan terulang di masa yang akan datang. Pada hakikatnya kegiatan pembelajaran yang dilakukan oleh guru dalam rangka mengembangkan potensi dan kecerdasan yang dimiliki oleh anak usia dini. Adapun kecerdasan merupakan kemampuan yang dimiliki oleh anak dalam menyeleseikan permasalahan yang dialami oleh anak dan kemampuan anak dalam menciptakan suatu karya atau hasil tertentu dalam kehidupannya (Gardner, 1993). Bagi seorang anak bermain adalah hidup dan hidup adalah bermain yang artinya melalui bermain anak belajar (Y. N. Sujiono, 2011). Namun yang terjadi di lapangan menunjukkan bahwa kegiatan pembelajaran yang disajikan guru PAUD belum didesain dengan kegiatan bermain yaitu dimana guru meminta anak untuk duduk tenang memperhatikan guru. Kenyataan lain yang terjadi di lapangan yaitu kegiatan pembelajaran masih bepusat pada guru (teacher center) dimana guru yang aktif sehingga dalam kegiatan pembelajaran yang terjadi belum memberikan kesempatan kepada anak untuk mengamati, bertanya, berekplorasi, dan mengkomunikasikan kegiatan pembelajaran dalam mengembangkan seluruh aspek perkembangan anak (meliputi kognitif, bahasa, fisik motorik, sosial emosional, seni, dan nilai agama moral). Artinya guru memaksa anak untuk melakukan kegiatan pembelajaran tanpa memperhatikan minat anak. Sebaiknya kegiatan pembelajaran yang dilakukan oleh guru yaitu berpusat pada anak (student center). Pendekatan student center yaitu suatu kegiatan pembelajaran yang terjadi interaksi antara anak dengan guru serta anak dengan anak, selain itu student center dapat mengarahkan anak untuk menjadi pemikir yang kritis, mampu membuat pilihan-pilihan dalam hidupnya, dan anak lebih kreatif serta imajinatif (Coughlin, 2000). Pada hakikatnya pendidik telah memiliki kemampuan merencanakan pembelajarn yang dapat mengembangkan multiple intelligensi anak dengan baik, sehingga dalam membuat perencanaan kegiatan pembelajaran membutuhkan kreativitas dengan memanfaatkan sumber daya yang dimiliki (kontekstual learning) (Laely, Astuti, \& Sari, 2020).

Delgoshaeia telah melakukan penelitian dengan menerapkan pendekatan multiple intelligences dalam mengembangkan kemampuan kognitif anak prasekolah. Hasil penelitian menunjukkan bahwa kemampuan kognitif anak dapat dikembangkan dengan menggunakan pendekatan multiple intelligences yaitu pendekatan yang memperhatikan kecerdasan ganda yang dimiliki oleh anak. Pada dasarnya anak satu dengan yang lainnya memiliki kecerdasan yang berbeda. Anak belajar melalui pengalaman kegiatan pembelajaran yang dialami oleh anak. Anak tidak hanya dipandang sebagai seseorang yang hanya menerima input pembelajaran saja namun setelah anak mendapatkan pengalaman pembelajaran maka anak akan memproses dan menghubungkan dengan pengalaman yang mereka miliki sebelumnya sehingga anak mendapatkan pengalaman untuk dapat menyeleseikan permasalahan atau kesulitan yang akan dialami anak di masa yang akan datang (Delgoshaei \& Delavari, 2012).

Selain itu (Kuo, Maker, Su, \& Hu, 2010) melakukan penelitian dengan mengidentifikasi anak yang berbakat, anak yang dapat menyeleseikan permasalahan, dan anak yang memiliki multiple intelligences. Hasil penelitian menunjukkan bahwa dengan stimulus atau kegiatan pembelajaran yang sesuai maka akan mendorong munculnya potensi-potensi yang dimiliki oleh anak. Selain itu juga memberikan kesempatan kepada anak yang memiliki keterbatasan fisik maupun non fisik untuk menemukan potensi yang dimiliki.

Adapun hal yang luput dari perhatian orang yaitu kegiatan dalam pembelajaran PAUD sudah seharusnya mengimplementasikan pendekatan saintifik (scientific approach) yang meliputi mengamati, menanya, menalar, mengumpulkan informasi, dan mengkomunikasikan (Kemendikbud, 2015). Seorang guru yang mampu 
mengimplementasikan pembelajaran saintifik secara tidak langsung sudah mampu mengimplemantasikan pembelajaran, dengan student center, dimana anak yang aktif dalam kegiatan bermainnya dan guru hanya sebagai fasilitator, pembelajaran yang mampu memunculkan rasa keingintahuan anak. Namun pada kenyataannya, dalam menyusun perencanaan dan melaksanakan kegiatan pembelajaran belum semua guru mampu mengimplementasikan pendekatan saintific (scientific approach).

Multiple Intelligences adalah sebuah penilaian yang melihat secara deskriptif bagaimana individu menggunakan kecerdasannya untuk memecahkan masalah dan menghasilkan sesuatu (Y. N. Sujiono, 2011). Dunia pendidikan mengakui multiple intelligences yaitu diantaranya kecerdasan linguistic (word smart), kecerdasan musical (musical smart), kecerdasan logika matematika (number smart), kecerdasan fisik dan kinestetik (body smart), kecerdasan intrapersonal (self smart), kecerdasan interpersonal (people smart), kecerdasan spasial (picture smart), kecerdasan naturalis (natural smart), dan kecerdasan spiritual (Y. N. Sujiono, 2011). Terimplementasinya scientific approach yang diimplementasikan dalam kegiatan bermain diharapkan mampu mengembangkan multiple intelligences anak usia dini. Kecerdasan sosial emosional yang tercakup dalam intrapersonal dan interpersonal yaitu kemampuan anak dalam mengenali dan mengelola emosi dirinya sendiri, memotivasi dirinya sendiri, mengenali emosi orang lain serta membangun hubungan yang baik dengan orang lain (Hasnidar, Sulihin, \& Elihami, 2020). Kecerdasan fisik khususnya motorik halus anak dapat distimulasi dengan kegiatan cooking class (Laely, Khusnul, 2020). Kecerdasan kinestetik anak mampu distimulai melakui kegiatan bermain egrang tempurung kelapa (Laely \& Yudi, 2015) serta bermain engklek (Laely \& Yudi, 2018). Sedangkan Kecerdasan linguistic anak dapat distimulasi dengan menggunakan media kartu gambar (Laely, 2013). Implementasi dalam kegiatan pembelajaran dalam mengembangkan multiple intelligensi anak di dalam maupun diluar kelas dapat dilakukan secara berkelompok baik satu kelompok terdiri dari 4 orang maupun 5 orang (Hasnidar \& Elihami, 2019).

Scientific Approach adalah suatu pendekatan yang digunakan dalam kegiatan pembelajaran anak usia dini meliputi mengamati, menanya, mengumpulkan informasi, menalar, dan mengkomunikasikan (Kemendikbud, 2015). Untuk dapat mengimplementasikan pendekatan ini membutuhkan kreatifitas guru dalam merancang kegiatan pembelajaran yang menyenangkan dan pembelajaran yang dapat menumbuhkan rasa keingintahuan anak yang dikemas dengan bermain (Mayesty, 1990). Hal ini dikarenakan dengan bermain mampu memberikan kesempatan kepada anak untuk berpikir sesuai dengan tahapannya dan memperoleh pengetahuan dari pengalaman bermainnya (Docket, 2000).

Hasil penelitian menunjukkan bahwa kemampuan perpikir secara ilmiah anak meningkat pesat ketika berada dalam usia dini. setiap anak usia dini memiliki perbedaan individu yang dapat stimulus untuk dapat berpikir secara ilmiah (scientific) dalam membentuk cara berpikir anak sesuai tahap berpikir ilmiah yaitu mengamati, menanya, mengumpulkan informasi, menalar, dan mengkomunikasikan sebagai bekal untuk kehidupan yang akan datang (Graaf, Segers, \& Verhoeven, 2018). Setiap anak mendapatkan pengetahuan dari pengalaman yang didapatkan dalam kegiatan bermain. Ketika anak berpikirnya sudah scientific diharapkan anak mampu berpikir logis sesuai tahap scientific berpikir anak. Pengetahuan yang didapatkan dari hasil pemikiran scientific tidak akan menggantikan pemikiran yang sudah dimiliki oleh anak sebelumnya, namun hanya dilakukan penekanan atau penalaran yang ada dalam tahap berpikir scientific untuk mendapatkan hasil pemikiran yang logis dan dapat diterima (Shtulman \& Valcarcel, 2012). Keterampilan proses sains anak dapat diimplementasikan dalam scientific approach. Ada beberapa faktor yang harus diperhatikan yaitu kecukupan material/ media yang digunakan dalam kegiatan pembelajaran, waktu yang cukup untuk anak berinteraksi dengan bahan ajar yang disiapkan oleh guru, dan kemampuan guru dalam memberikan provokasi ke anak untuk melakukan kegiatan pembelajaran (Rahardjo, 2014). Keterampilan kognitif anak dapat dikembangkan 
Implementasi Scientific Approach dalam Mengembangkan Multiple Intelligences Anak Usia Dini DOI: $10.31004 /$ obsesi.v5i2.730

melalui kegiatan pembelajaran yang dikemas dengan pembelajaran saintifik (Made, Suryaningsih, \& Rimpiati, 2018).

Pada hakikatnya anak usia dini memiliki kemampuan terbatas dalam memecahkan masalah ilmiah maupun mepelajari konsep-konsep sains, namun penelitian menunjukkan bahwa scientific merupakan salah satu pendekatan yang dapat digunakan oleh pendidik atau orang tua dalam mengenalkan, memahami dan mempelajari konsep sains tertentu ( misalnya konsep tenggelam dan terapung) serta mengembangkan kosakata yang dimiliki oleh anak. Semua tujuan pembelajaran akan tercapai ketika stimulus yang diberikan juga sesuai yaitu dikemas dengan kegiatan yang menyenangkan dalam kegiatan bermain (Hong \& Diamond, 2012). Rasa ingin tahu yang dimiliki oleh anak merupakan salah satu yang mendorong anak untuk berpikir ilmiah (scientific) untuk melakukan percobaan dan eksplorasi dalam memahami suatu konsep tertentu (Jirout \& Klahr, 2012). Pendidik dalam hal ini orang dewasa baik orang tua maupun guru untuk senantiasa merencanakan kegiatan pembelajaran yang dapat menimbulkan rasa keingintahuan anak (Loewenstein, 1994).

Anak lahir sudah dianugerahi kecerdasan dan akan semakin berkembang seiring perkembangannya. Berkembang atau tidaknya kecerdasan seseorang tergantung pada stimulus yang didapatkan. Kecerdasan yang dimiliki oleh seseorang dapat membantu memecahkan masalah yang dihadapi dalam kehidupannya (Sujiono, Yuliani Nurani, 2010). Penelitian yang telah dilakukan oleh Gardner mendapatkan hasil bahwa kecerdasan manusia bersifat satuan dan setiap individu merupakan seorang makhluk yang kecerdasaanya dapat diukur. Adapun temuannya diantaranya yaitu setiap kecerdasan yang dimiliki oleh seorang anak bekerjasama satu sama lain dan setiap anak dapat mengembangkan kecerdasannya sampai suatu tingkat tertentu (Campbell, Linda, 2002).

Multiple intelligences ini berpengaruh terhadap orientasi pembelajaran. Menurut teori ini apabila materi disajikan sesuai dengan kecerdasan yang dimiliki oleh anak, maka anak akan semakin mudah dalam memahami inti pembelajaran. Oleh karena itu, sebagai seorang pendidik dan guru harus mengetahui kecerdasan yang menonjol dari anak kita, sehingga dapat menyajikan materi atau stimulus yang mendorong berkembangnya kecerdasan tersebut secara pesat (Hamzah, 2009). Bagi seorang Gardner tidak ada anak yang pintar maupun anak yang bodoh, namun sebaliknya yang ada hanya anak yang menonjol pada berbagai kecerdasan (Sujiono, Yuliani Nurani, 2010). Berdasarkan beberapa pendapat diatas, maka sebagai orang tua sebaiknya cermat dan jeli dalam memberikan stimulus yang dapat mengembangkan kecerdasan anak.

Tahap berpikir saintifik meliputi mengamati, menanya, mengumpulkan informasi, menalar, dan mengkomunikasikan. Setiap anak usia dini memiliki perbedaan individu yang dapat stimulus untuk dapat berpikir secara ilmiah (scientific) dalam membentuk cara berpikir anak sesuai tahap berpikir ilmiah yaitu mengamati, menanya, mengumpulkan informasi, menalar, dan mengkomunikasikan sebagai bekal untuk kehidupan yang akan datang (Graaf et al., 2018). Sedangkan Sembilan kecerdasan yang terkemas dalam multiple intelligences yaitu diantaranya kecerdasan linguistic (Word Smart), kecerdasan musical (Musical Smart), kecerdasan logika matematika (Number Smart), Kecerdasan fisik dan kinestetik (Body Smart), Kecerdasan intrapersonal (Self Smart), Kecerdasan interpersonal (People Smart), Kecerdasan spasial (Picture Smart), Kecerdasan naturalis (Natural Smart), dan Kecerdasan spiritual (Y. N. Sujiono, 2011). Hal ini berarti dalam proses Scientific Approach secara tidak langsung dapat mengembangan kecerdasan jamak yang dimiliki oleh anak. Implementasi saintifik approach dengan melakukan kegiatan budidaya tanaman di lembaga PAUD dapat mengembangkan kecerdasan naturalis anak yaitu anak mengetahui berbagai ciptaan Allah, menumbuhkan rasa syukur adanya keberadaan tanaman ciptaan Allah sehingga dapat memanfaatkan keberadaannya, serta bagaimana cara merawat ciptaan Allah dengan baik (Slamet \& Kurniati, 2018). 


\section{METODOLOGI}

Metode penelitian yang digunakan dalam penelitian ini yaitu metode survey. Penelitian bertujuan untuk mengetahui kondisi maupun fenomena yang ada di lapangan. Data diperoleh melalui wawancara, angket, dan pengamatan langsung (observasi). Data penelitian dalam penelitian ini akan dianalisis menggunakan analisis deskriptif kuantitatif. Hasil analisis angka akan dijelaskan secara deskriptif. Berdasarkan jenis pendekatan penelitian deskriptif kuantitatif, maka peneliti akan mendeskripsikan dan menganalisis tentang implementasi Scientific Approach dalam mengembangkan Multiple Intelligences Anak Usia Dini

Penelitian ini dilakukan di 9 lembaga pendidikan anak usia dini baik kelompok bermain maupun Taman Kanak-kanak, Raudhatul Athfal, dan Bustanul Athfal yang berada di Kabupaten Kebumen, Kabupaten Wonosobo, dan Kabupaten Temanggung. Subyek yang diambil merupakan lembaga yang terakreditasi baik A, B, dan C sehingga sudah mewakili dari setiap kebupaten yang berada di Karisidenan Kedu.

Adapun prosedur penelitian diawali dengan (a) Penyusunan angket, pedoman wawancara dan lembar observasi untuk panduan pengamatan langsung kegiatan pembelajaran; (b) Peneliti melakukan wawancara kepada kepala sekolah dan guru untuk mengetahui sejauh mana implementasi Scientific Approach dalam mengembangkan multiple intelligences anak usia dini; (c) Peneliti mengamati implementasi Scientific Approach dalam mengembangkan multiple intelligences anak dalam kegiatan pembelajaran; (d) Berdasarkan hasil jawaban wawancara, dan hasil observasi secara langsung dalam proses kegiatan pembelajaran, peneliti mengidentifikasikan implementasi Scientific Approach dalam mengembangkan multiple intelligences anak usia dini. Alur penelitian dapat dilihat pada gambar 1 .

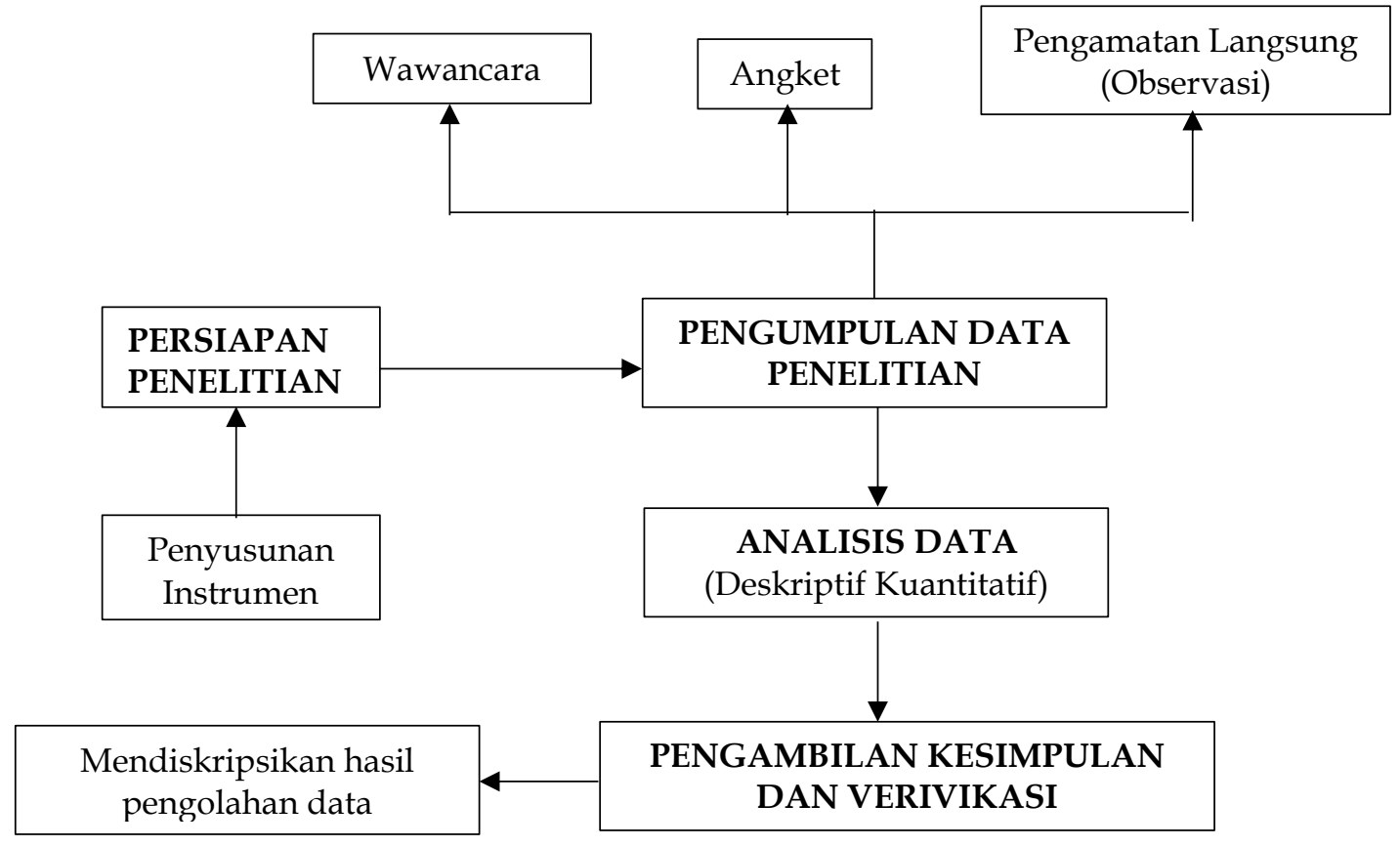

Gambar 1. Alur Pelaksanaan Penelitian

\section{HASIL DAN PEMBAHASAN}

\section{Perencanaan Satuan PAUD dalam Kegiatan Pembelajaran}

Anak usia dini merupakan sosok individu yang sedang mengalami perkembangan yang pesat dalam kehidupannya. Anak belajar melalui pengalaman yang dialami anak sepanjang kehidupannya. Ketika anak lahir kedunia, Allah telah menganugrahkan potensi dan kemampuan. Namun, potensi dan kemampuan yang dimiliki anak ini akan berkembang ketika anak mendapatkan stimulasi dari orang tua, pendidik, lingkungan sekitar, serta pengalamannya dalam bermain. Oleh karena itu kita sebagai orang tua dan pendidik 
Implementasi Scientific Approach dalam Mengembangkan Multiple Intelligences Anak Usia Dini DOI: 10.31004/obsesi.v5i2.730

senantiasa selalu mendesain kegiatan pembelajaran anak untuk memunculkan dan mengembangkan potensi anak. Usia dini adalah usia bermain, dimana kegiatan pembelajaran dikemas dengan kegiatan bermain. Bermain merupakan kebutuhan bagi anak, hal ini dikarenakan melalui bermain anak akan mendapatkan pengetahuan untuk mengembangan seluruh kemampuan anak. Kompetensi dan kemampuan anak berkembang sesuai stimulasi yang diberikan oleh orang tua dan pendidik.

Sebagai pendidik sudah seharusnya memiliki kompetensi dalam merencanakan kegiatan pembelajaran yang dilakukan sehari-hari untuk sesuai dengan layanan usia. Indikator yang dikembangkan sesuai dengan indicator layanan usia yang tercantum dalam Satuan Tingkat Pencapaian Perkembangan Anak (STPPA). Pemberian stimulasi ini diharapkan dapat mengembangkan seluruh aspek perkembangan anak meliputi agama moral, bahasa, kognitif, sosial emosional, kognitif, dan seni. Seluruh aspek perkembangan anak akan berkembang sesuai dengan harapan ketika pembelajaran yang diimplementasikan dalam kehidupan sehari hari dilakukan perencanaan dalam Rencana Pelaksanaan Pembelajaran Harian (RPPH) sesuai dengan kurikulum yang sudah ditetapkan sebelum kegiatan pembelajaran berlangsung. Setelah peneliti melakukan penelitian, maka didapatkan data pada tabel 1.

Tabel 1 Data Satuan PAUD dalam Melaksanaan Perencanaan Kegiatan Pembelajaran

\begin{tabular}{llcc}
\hline No & \multicolumn{1}{c}{ Indikator } & N & Temuan \\
\hline 1 & $\begin{array}{l}\text { Satuan PAUD merencanakan pembelajaran sesuai dengan tahapan } \\
\text { perkembangan anak. }\end{array}$ & 9 & $100 \%$ \\
2 & $\begin{array}{l}\text { Guru melakukan penataan lingkungan main } \\
3\end{array}$ & 9 & $100 \%$ \\
& $\begin{array}{l}\text { Satuan PAUD melaksanakan kegiatan pembelajaran sesuai dengan Rencana Pelaksanaan Pembelajaran Harian (RPPH). } \\
\text { RPPM }\end{array}$ & 9 & $66,77 \%$ \\
& $\begin{array}{l}\text { Guru menyediakan ragam kegiatan main dalam satu hari sebagai } \\
\text { pilihan main anak. }\end{array}$ & $97,78 \%$ \\
\hline
\end{tabular}

Dari data pada tabel 1 dapat disimpulkan bahwa Satuan PAUD di Karisidenan Kedu, $100 \%$ sudah melakukan perencanaan kegiatan pembelajaran sebelum kegiatan pembelajaran berlangsung. Adapun perencanaan pembelajaran yang dimiliki termuat dalam kurikulum lembaga. Perencanaan pembelajaran yang direncanakan satuan PAUD diwujudkan dalam bentuk RPPM (Rencana Pelaksanaan Pembelajaran Mingguan) dan RPPH (Rencana Pelaksanaan Pembelajaran Harian). Baik RPPM dan RPPH yang disusun oleh satuan PAUD, indicator yang dikembangkan telah disesuaikan dengan layanan usia yang tercantum dalam Satuan Tingkat Pencapaian Perkembangan (STPPA) yang termuat dalam lampiran I Permendikbud 137 Tahun 2014 tentang Standar Nasional Pendidikan Anak usia Dini.

Satuan lembaga PAUD yang berada di Karisidenan Kedu 100 \% guru juga sudah melakukan penataan ragam main sesuai dengan perencanaan yang telah dilakukan. Hal ini teramati ketika kegiatan penelitian dilakukan saat peneliti datang ke lembaga dipagi hari, guru-guru yang berada di satuan lembaga telah menata ragam main sesuai dengan perencanaan yang telah disusun.

Satuan lembaga PAUD sudah memiliki perangkat pembelajaran yang didalamnya RPPM dan RPPH sebagai prasyarat seorang guru dalam melakukan kegiatan pembelajaran. Namun RPPH yang disusun belum semuanya singkron dengan RPPM yang dimiliki lembaga. Hasil penelitian menunjukkan baru 66,77 \% satuan lembaga yang menyusun RPPH dan dokumen yang dimiliki sesuai dengan dokumen RPPM nya.

Kegiatan pembelajaran akan menyenangkan apabila dalam kegiatan pembelajaran guru merencanakan dan menyiapkan banyak pilihan ragam main. Ragam main yang disajikan saat peneliti melakukan penelitian dilapangan masih ada satuan PAUD yang menyediakan dan menata 2 dan 3 ragam main dalam satu hari. Sedangkan satuan lembaga se Karisidenan Kedu yang menyiapkan 4 ragam main mencapai 77,78 \% 


\section{Implementasi Scientific Approach}

Peneliti melakukan observasi langsung di lembaga PAUD untuk mengetahui sejauh mana tahap Scientific Approach yang dilalui anak dalam mengikuti kegiatan pembelajaran. Tahap-tahap dalam Scientific Approach meliputi mengamati, menanya, mengumpulkan informasi, menalar dan mengkomunikasikan hasil pembelajaran yang dilalui oleh anak. Setelah peneliti melakukan observasi lapangan saat penelitian, maka peneliti mendapatkan data implementasi Scientific Approach pada tabel 2.

Tabel 2. Data Implementasi Scientific Approach di satuan PAUD se Karisidena Kedu

\begin{tabular}{clcc}
\hline No & \multicolumn{1}{c}{ Indikator } & N & Temuan \\
\hline 1 & Tahap mengamati & 9 & $11,11 \%$ \\
2 & Tahap mengamati dan menanya & 9 & $22,22 \%$ \\
3 & Tahap mengamati, menanya, mengumpulkan informasi & 9 & $11,11 \%$ \\
4 & Tahap mengamati, menanya, mengumpulkan informasi, menalar & 9 & $11,11 \%$ \\
5 & $\begin{array}{l}\text { Tahap mengamati, menanya, mengumpulkan informasi, menalar } \\
\text { dan mengkomunikasikan }\end{array}$ & 9 & $44,44 \%$ \\
\hline
\end{tabular}

Data Implementasi Scientific Approach di satuan PAUD se Karisidena Kedu di atas menunjukkan bahwa satuan lembaga yang melakukan kegiatan pembelajaran dengan mengimplementasikan Scientific Approach baru mencapai 44,44 \%. Hal ini menunjukkan bahwa pembelajaran yang dilakukan satuan PAUD belum maksimal dalam memberikan kesempatan anak untuk mengamati, menanya, mengumpulkan informasi, menalar dan mengkomunikasikan. Artinya kegiatan pembelajaran yang diberikan belum mampu menggali kemampuan-kemampuan anak untuk mampu berpikir kritis.

\section{Multiple Intelligences yang dikembangkan melalui Pendekatan Scientific Approach}

Pada hakikatnya sebagai orang tua dan pendidik kita harus memahami multiple intelligences. Hal ini dikarenakan dengan pendidik dan orang tua memahami multiple intelligences ini dapat mengetahui kecerdasan yang dimiliki oleh anak kita dan dapat menstimulasi kecerdasan yang dimilikinya. Berdasarkan hasil observasi di lapangan Multiple Intelligence yang dapat distimulasi melalui Scientific Approach dapat diamati pada tabel 3.

\section{Pembahasan}

Berdasarkan hasil penelitian Implementasi Scientific Approach dalam Mengembangkan Multiple Intelligences Anak Usia Dini ini menunjukkan bahwa satuan PAUD se Karisidenan Kedu sudah melaksanakan kegiatan pembelajaran yang dikemas dengan bermain. Hal ini sejalan dengan pendapat (Docket, 2000) bahwasannya bermain merupakan suatu kebutuhan anak usia dini untuk mengembangkan seluruh kemampuan dan potensi yang dimilikinya. Lembaga Satuan PAUD se Karisidenan kedu dalam melakukan kegiatan pembelajaran sudah diawali dengan menyusun perencanaan. Namun, perangkat pembelajaran yang disusun tingkat kesesuaian antara RPPH dan RPPM mencapai 66,77 \%. Selain itu juga kemampuan guru dalam merencanakan ragam main dalam satu hari sebagai pilihan main anak mencapai 77,78 \%. Hal ini membuktikan bahwa kemampuan guru dalam menyusun perencanaan kegiatan pembelajaran masih belum optimal, sehingga masih dirasa perlu untuk meningkatkan kemampuannya untuk dapat lebih kreatif dalam mengembangkan kegiatan pembelajaran yang dikemas dengan bermain.

Hasil penelitian menunjukkan bahwa implementasikan kegiatan pembelajaran dengan menggunakan Scientific Approach mencapai 44,44 \%. Hal ini didasarkan pada hasil penelitian dilapangan, guru di lembaga PAUD se Karisidenan Kedu belum semua mampu memberikan kesempatan kepada anak untuk memberikan kesempatan anak mulai dari mengamati, menanya, mengumpulkan informasi, menalar sampai pada mengkomunikasikan. Dengan demikian, maka masih perlu dilakukan kegiatan atau pelatihan yang dapat 
Implementasi Scientific Approach dalam Mengembangkan Multiple Intelligences Anak Usia Dini DOI: 10.31004/obsesi.v5i2.730

meningkatkan kemampuan dan kompetensi guru khususnya kompetensi Pedagogi (dalam Peraturan Pemerintah No.19 Tahun 2005).

Tabel 3. Multiple Intelligences yang dikembangkan melalui Pendekatan Scientific Approach

\begin{tabular}{|c|c|c|}
\hline No & $\begin{array}{l}\text { Multiple } \\
\text { Intelligences }\end{array}$ & Kegiatan yang Menstimulasi \\
\hline 1 & $\begin{array}{l}\text { Kecerdasan } \\
\text { Linguistic } \\
\text { (Word Smart) }\end{array}$ & $\begin{array}{l}\text { Kegiatan bermain kartu huruf menghubungkan gambar dan tulisan, } \\
\text { menempel angka } 7 \text {, Menempelkan kartu huruf membentuk kata teko, } \\
\text { bermain menjepit kartu huruf, menebalkan tulisan ibu, menempel huruf } \\
\text { ayah, menulis kata tangan, dan menulis huruf " } \mathrm{t} \text { ", }\end{array}$ \\
\hline 2 & $\begin{array}{l}\text { Kecerdasan } \\
\text { Musical } \\
\text { (Musical Smart) }\end{array}$ & $\begin{array}{l}\text { Kegiatan menyanyi sambil menari kuda lumping, menyanyi lonceng } \\
\text { berbunyi, menyanyi suara hewan, menyanyi macam-macam buah, dan } \\
\text { menyanyi anoman. }\end{array}$ \\
\hline 3 & $\begin{array}{l}\text { Kecerdasan } \\
\text { Logika } \\
\text { Matematika } \\
\text { (Number Smart) }\end{array}$ & $\begin{array}{l}\text { Kegiatan Mengurutkan pertumbuhan pohon pisang, menghitung biji salak, } \\
\text { menghitung gelas plastic, menempel angka } 7 \text {, Mebuat bakso dari tanah liat, } \\
\text { melipat sapu tangan dan mengelompokkannya, mengurutkan bilangan } \\
\text { dengan gambrar, dan kegiatan menghitng jari tangan. }\end{array}$ \\
\hline 4 & $\begin{array}{l}\text { Kecerdasan } \\
\text { Fisik Motorik } \\
\text { dan Kinestetik } \\
\text { (Body Smart) }\end{array}$ & $\begin{array}{l}\text { Kegiatan bergelantungan di bola dunia, bermain lempar tangkap bola, } \\
\text { bermain memindah bola, mencetak dengan pelepah pisang, membuat } \\
\text { mainan dari pelepah pisang, menggambar salak dan menulis huruf salak, } \\
\text { kolase dengan kulit salak, membuat manisan dari carica, kolase buah } \\
\text { carica, menggambar alat-alat untuk minum, menghias teko denga cutton } \\
\text { bud dan pewarna, menempelkan kartu huruf membentuk kata teko, } \\
\text { membuat jus jambu, membuat bakso dari tanah liat. }\end{array}$ \\
\hline 5 & $\begin{array}{l}\text { Kecerdasan } \\
\text { Intrapersonal } \\
\text { (Self Smart) }\end{array}$ & $\begin{array}{l}\text { Kegiatan pembiasaan berbagi, berempati kepada teman, melalui menonton } \\
\text { video yang memiliki nilai kejujuran. }\end{array}$ \\
\hline 6 & $\begin{array}{l}\text { Kecerdasan } \\
\text { interpersonal } \\
\text { (People Smart) }\end{array}$ & $\begin{array}{l}\text { Kegiatan pembiasaan meminta maaf ketika melakukan kesalahan, } \\
\text { pembiasaan saling membatu dengan sesama teman, pembiasaan } \\
\text { membantu orang yang ada disekitarnya. }\end{array}$ \\
\hline 7 & $\begin{array}{l}\text { Kecerdasan } \\
\text { Spasial (Picture } \\
\text { Smart) }\end{array}$ & $\begin{array}{l}\text { Kegiatan Mencetak dengan pelepah pisang, membuat mainan dari pelepah } \\
\text { pisang, menggambar salak dan menulis kata salak, kolase dengan kulit } \\
\text { salak, kolase buah carica menggambar alat-alat untuk minum. }\end{array}$ \\
\hline 8 & $\begin{array}{l}\text { Kecerdasan } \\
\text { Naturalis } \\
\text { (Natural Smart) }\end{array}$ & $\begin{array}{l}\text { Kegiatan mencetak dengan pelepah pisang, membuat mainan dari pelepah } \\
\text { pisang, mengurutkan pertumbuhan pohon pisang, menghitung biji salak, } \\
\text { menanam biji salak ke polybag, menggambar salak dan menulis huruf salak, } \\
\text { kolase dengan kulit salak, membuat manisan dari carica, kolase buah } \\
\text { carica, membuat juz jambu, membuat bakso dari tanah liat, dan membuat } \\
\text { salad buah. }\end{array}$ \\
\hline 9 & $\begin{array}{l}\text { Kecerdasan } \\
\text { Spiritual }\end{array}$ & $\begin{array}{l}\text { Pembiasaan-pembiasaan membaca surat pendek, doa-doa harian, asmaul } \\
\text { husna, bercerita dengan boneka jari tentang kejujuran. }\end{array}$ \\
\hline
\end{tabular}

Hasil penelitian yang menunjukkan implementasikan kegiatan pembelajaran dengan menggunakan Scientific Approach baru mencapai 44,44 \% telah mampu mengembangkan multiple intelligences anak usia dini yang meliputi kecerdasan linguistic (Word Smart), kecerdasan musical (Musical Smart), kecerdasan logika matematika (Number Smart), Kecerdasan fisik dan kinestetik (Body Smart), Kecerdasan intrapersonal (Self Smart), Kecerdasan interpersonal (People Smart), Kecerdasan spasial (Picture Smart), Kecerdasan naturalis (Natural Smart), dan Kecerdasan spiritual (Y. N. Sujiono, 2011).

\section{SIMPULAN}

Implementasikan kegiatan pembelajaran dengan menggunakan Scientific Approach mencapai 44,44 \%. Hal ini menunjukkan bahwa guru di lembaga PAUD se Karisidenan Kedu belum semua mampu memberikan kesempatan kepada anak untuk memberikan kesempatan 
anak mulai dari mengamati, menanya, mengumpulkan informasi, menalar sampai pada mengkomunikasikan. Meskipun demikian, pembelajaran dengan menggunakan Scientific Approach dapat menstimulasi multiple intelligences anak usia dini pada setiap kecerdasan anak.

\section{UCAPAN TERIMA KASIH}

Ucapan terimakasih dipersembahkan untuk Lembaga Penelitian Pengembangan dan Pengabdian kepada Masyarakat (LP3M) Universitas Muhammadiyah magelang yang telah mendanai penelitian ini melalui SKIM Penelitian Revitalisasi Visi Instituurusi (PRVI).

\section{DAFTAR PUSTAKA}

Campbell, Linda, B. C. dan D. D. (2002). Teaching and Learning through Multiple Intelligences. Depok: Inisiasi Press.

Coughlin, P. A. dkk. (2000). Menciptakan Kelas yang Berpusat pada Anak. Washington, D C: Children's Resources International.

Delgoshaei, Y., \& Delavari, N. (2012). Applying multiple-intelligence approach to education and analyzing its impact on cognitive development of pre-school children, 00(2010), 361-366. https:/ / doi.org/10.1016/j.sbspro.2012.01.054

Docket, S.; M. F. (2000). Play and Pedagogy in Early Childhood-Bending the Rules (Sidney). Harcourt.

Gardner, H. (1993). Multiple Intelligences: The Theory in Practice A READER. USA: Basicbooks.

Graaf, J. Van Der, Segers, E., \& Verhoeven, L. (2018). Individual di ff erences in the development of scienti fi c thinking in kindergarten, 56(December 2016), 1-9. https:// doi.org/10.1016/j.learninstruc.2018.03.005

Hainstock, E. G. (1999). Metode Pengajaran Montessori untuk Anak Prasekolah. Jakarta: Pustaka Delapratasa.

Hamzah, A. (2009). Teori Multiple Intelligences dan Implikasinya Terhadap Pengelolaan Pembelajaran. Tadris, 4.

Hasnidar, H., \& Elihami, E. (2019). The management Model of National Character Education for Early Childhood Education through based on Democracy, 3(1), 14-19.

Hasnidar, H., Sulihin, S., \& Elihami, E. (2020). Developing of Multiple Intelligences in students with the Two Stay Two Strays Type, 4(2), 7-12.

Hong, S., \& Diamond, K. E. (2012). Early Childhood Research Quarterly Two approaches to teaching young children science concepts, vocabulary, and scientific problem-solving skills. Early Childhood Research Quarterly, 27(2), 295-305. https:// doi.org/10.1016/j.ecresq.2011.09.006

Jirout, J., \& Klahr, D. (2012). Children' s scientific curiosity: In search of an operational definition of an elusive concept q. Developmental Review, 32(2), 125-160. https:// doi.org/10.1016/j.dr.2012.04.002

Kemendikbud. (2015). Petunjuk Teknis Penyelenggaraan Taman Kanak-Kanak. Direktorat Jendral Pendidikan Anak Usia Dini dan Pendidikan Masyarakat.

Kuo, C., Maker, J., Su, F., \& Hu, C. (2010). Identifying young gifted children and cultivating problem solving abilities and multiple intelligences. Learning and Individual Differences, 20(4), 365-379. https:// doi.org/10.1016/j.lindif.2010.05.005

Laely, Khusnul, S. (2020). Cooking Class Berbasis Kearifan Lokal Meningkatkan Motorik Halus Anak di Daerah Miskin. Jurnal Obsesi : Jurnal Pendidikan Anak Usia Dini, 4(2), $923-$ 931. https://doi.org/10.31004/obsesi.v4i2.466

Laely, K. (2013). Peningkatan Kemampuan Membaca Permulaan Melalui Penerapan Media Kartu Gambar. Jurnal Pendidikan Anak Usia Dini, 7(2), 301-320.

Laely, K., Astuti, F. P., \& Sari, D. L. (2020). Analysis of Teachers Abilities in Implementing Contextual Learning to Develop Multiple Intelligences of Early Childhood. Journal of Critical Reviews, 7(9), 1135-1137.

Laely, K., \& Yudi, D. (2015). Pengaruh Permainan Egrang Tempurung Kelapa Terhadap 
Peningkatan Kecerdasan Kinestetik Anak. Jurnal EMPOWERMENT, 3(1), 32-41.

Laely, K., \& Yudi, D. (2018). The Impact of Hopscotch Game towards the Growth of Kinesthetic Intelligence on 3-4 Year Old Children. ECRJ Early Childhood Research Journal, 1(1), 2128.

Loewenstein, G. (1994). The psychology of curiosity: A review and reinterpretation. Psychological Bulletin,. Psychological Bulletin, 1(116), 75-98.

Made, N., Suryaningsih, A., \& Rimpiati, N. L. (2018). Implementation of Game-Based Thematic Science Approach in Developing Early Childhood Cognitive Capabilities. Jurnal Obsesi: Jurnal Pendidikan Anak Usia Dini, 2(2), 194-201. https://doi.org/10.31004/obsesi.v2i2.90

Mayesty, M. (1990). Creative Activities for Young Children 4th: Play, Development, and Creativity. New York: Delmar Publishe rInc.,.

Rahardjo, M. M. (2014). Implementasi Pendekatan Saintifik Sebagai Pembentuk Keterampilan Proses Sains Anak Usia Dini. Scholaria: Jurnal Pendidikan Dan Kebudayaan, 9(2), 148-159.

Shtulman, A., \& Valcarcel, J. (2012). Scientific knowledge suppresses but does not supplant earlier intuitions. Cognition, 209-215. https:/ / doi.org/10.1016/j.cognition.2012.04.005

Slamet, A., \& Kurniati, A. (2018). Scientific Approach in Imparting Islamic Values In Early Childhood: A case study in Raudatul Aisyiyah Athfal Baubau, 25(1), 71-76.

Sujiono, Yuliani Nurani, B. S. (2010). Bermain Kreatif Berbasis Kecerdasan Jamak. (D. Y. N. Sujiono \& D. B. Sujiono, Eds.). Jakarta: PT Indeks.

Sujiono, Y. N. (2011). Konsep Dasar Pendidikan Anak usia Dini (Keempat). Jakarta: PT Indeks. 